NBER WORKING PAPER SERIES

A THEORY OF EXPROPRIATION AND DEVIATIONS

FROM PERFECT CAPITAL MOBILITY

Jonathan Eaton

Mark Gersovitz

Working Paper No. 972

NATIONAL BUREAU OF ECONOMIC RESEARCH

1050 Massachusetts Avenue

Cambridge MA 02138

August 1982

This paper represents a revised version of a paper which appeared under the same title as Discussion Paper No. 93, Princeton Research Program in Development Studies, Princeton University, in December 1980. We would like to thank Gene M. Grossman, Ronald W. Jones, Larry A. Sjaastad, Nicholas H. Stern and Joseph E. Stiglitz for comments and suggestions. Much of Eaton's work on this paper was completed while he was a visitor at the Graduate Institute for International Studies, Geneva. The research reported here is part of the NBER's research program in International Studies. Any opinions expressed are those of the authors and not those of the National Bureau of Economic Research. 


\section{A Theory of Fxpropriation and Deviations \\ From Perfect Capital Mobility}

\section{ABSTRACT}

This paper develops a theory of capital movements in the presence of potential expropriation. The threat of expropriation is derived from utility maximizing behavior by host countries. Potential investors, anticipating this behavior, modify their investment plans to avoid expropriation. Whenever the host country faces competitive foreign investors expropriation represents part of a time-consistent but suboptimal plan of the type discussed by Kydland and Prescott (1977). The consequent equilibrium may be characterized by a number of distortions.

In the simplest model we analyse, a host country faces a large number of potential, competitive foreign investors. We explore the implications of the threat of expropriation for shadow pricing in the host country and for the optimal technology choice by potential investors. We consider variants. of the model in which the potential investor is in a monopoly position vis-avis the host country, in which the foreign investment project is subject to risk which is unresolved at the time of the expropriation decision, and in which factors affecting the optimality of expropriation by the host country are unresolved at the time of the investment decision.

The larger the penalty incumbent on the host country in the event of expropriation, the greater its welfare in the simple, competitive model. When the foreign investor is a monopolist, however, this result is reversed.

Jonathan Eat on

Economic Growth Center Yale University Box 1987, Yale Station New Haven, Connecticut 06520

(203) 436-8414
Mark Gersovitz Woodrow Wilson School Princeton University Princeton, New Jersey 08455 (609) $452-4794$ 


\section{Introduction}

Many factors prevent commodity trade from equalizing the rewards to - factors of production in different countries, providing an incentive for factor movements between countries. While movements of factors, especially capital, are important in the world economy, they have not been sufficient to equate factor returns among countries.

The failure of capital flows to equate rates of return on capital is frequently attributed to political risks and left outside the sphere of economic analysis. Specifically, investments abroad, especially in LDC's, are said to be more subject to the risk of expropriation, or at least to unpredictable changes in the tax and exchange control regime offered by the host country. Williams (1975) estimates that about twenty percent of the value of foreign investments carried into or made during 1956-72 in LDC's was expropriated without compensation in this period. Rather than consigning the study of these phenomena to other disciplines, we argue that an important set of economic considerations affect the nature of these impediments to capital mobility.

In this paper, we provide a theory of expropriation based on maximizing behavior by investors and host countries. This theory can be used to identify Industry and national characteristics that increase the threat of expropriation and imply large deviations from equalized rates of return on capital. 1 We examine host country and parent country policies minimizing the distortions associated with the threat of expropriation.

Three broad conclusions follow from the analysis. First, the threat of expropriation implies significant distortions in the international allocation of capital even though the act of expropriation may be relatively 
rare. For instance, in a world of perfect foresight and rational decisionmaking, acts of expropriation would never occur and yet the actions by investors taken to ensure that countries do not expropriate are distorting. Second, the ability of governments to expropriate foreign investments may actually reduce their own welfare. Further, the hosts may be better off if investor country governments can retaliate against expropriating countries. Indeed, the higher this penalty, the more their welfare may be increased. This conclusion arises because a government's power to expropriate after investments are made leads investors to restrict their investments beforehand in a way that makes the host country worse off than it would be if it could not expropriate, yielding an example of the general paradox of time inconsistency (Kydland and Prescott, 1977).

Third, domestic factor prices may not accurately reflect social returns when the threat of expropriation affects the supply of foreign investment. The social rate of return on capital may exceed its domestic marginal product while the social rate of return on any factor supplied by foreigners and not expropriable may be less than the marginal product of that factor. This result has implications for project evaluation in LDC's.

In Section 2 we present a simple model of foreign investment with potential expropriation based on MacDougall's (1958) work on foreign investment in the absence of expropriation. A small country produces a single output with three factors. Labor is supplied domestically in a fixed amount and is not internationally mobile. Two other factors, capital and management, are internationally mobile. These two factors differ in that capital can be expropriated; management cannot be. For our purposes, capital represents the tangible aspects of foreign investment: plant, equipment, inventories and 
other properties left behind after expropriation. Managerial services are the intangible assets that a foreign investor brings to the production process: technical knowledge, organizational capabilities, access to overseas markets and the like. Essential to our analysis is the assumption that if expropriation occurs, the managerial services of the foreign investor are no longer avallable and cannot be replaced by other foreigners. This situation may arise because foreign managers boycott the expropriating country or because the capital installed by foreign investors is specific to its own managerial skills. Ex post the firm's managers may have a unique ability to operate that firm's capital.

In deciding on expropriation, a host country must weigh the benefits of obtaining income from foreign capital and the ownership of the capital itself against the costs of losing access to foreign managerial services. For many levels of foreign investment, including the one equating the domestic marginal product of capital to the world interest rate, the benefits of expropriation may outweigh the costs. Foreign investors will not increase their investments to the point where expropriation becomes optimal. If the threat of expropriation is binding, the level of foreign investment and national income will be determined by competition among investors and the capacity of the host country to absorb foreign investment without expropriation. In Section 2 we examine the determinants of this equilibrium and the effects of changes in national factor endowments and world factor prices on this equilibrium. We also investigate the effects of the threat of expropriation on the distribution of income among national factors. Section 3 examines the associated consequences of the threat of expropriation for project evaluation and optimal investment decisions in host countries. 
In Section 4 we consider the case of a foreign investor who is a monopolist vis-a-vis a number of potential host countries. The monopolistic investor will always invest less than competitive investors for a given technology. National income will also be lower.

Section 5 examines the consequences of expropriation for technical choice. We show that when a parameter of the production function (e.g., the elasticity of substitution) is a choice variable for the investors, investors may distort the technology to reduce the threat of expropriation. Because of this type of distortion, the threat of expropriation may raise the equilibrium level of investment above the level obtaining under perfect capital mobility. Furthermore, the monopolistic investor may actually invest more than competitive investors, but the host country is still worse off than if the foreign investors were competitive.

In Section 6 we return to the assumption that investors are competitive but assume that projects are risky and that expropriation transfers this risk to the host country. Risk bearing rather than managerial skill is the contribution of foreign investors that cannot be expropriated. A host can benefit from increases in the riskiness of projects if it is risk averse while foreign investors are not, since risk reduces the threat of expropriation.

In Section 6 we assume that the risk tnherent in foreign investment is not resolved until after the expropriation decision must be made. This assumption is appropriate to profects where the risk is ongoing, e.g., agricultural projects subject to annual differences in weather or projects producing output sold in volatile international markets. For other types of projects, uncertainty is resolved before the expropriation decision must be made. This situation may prevail in extractive activity where a mineral discovery resolves the uncertainty before production begins. In Section 7 
we assume that the national endowment of managerial services is a random variable revealed after the investment decision has been made but before the host country decides on expropriation. In this model expropriations can actually occur, in contrast with our previous models. Foreign investors act knowing of this risk.

Our model applies specifically to capital movements in the form of direct investment. The host country imports not only foreign capital but foreign entrepreneurship as well, either in the form of managerial services or risk bearing. The penalty of expropriation is the loss of this entrepreneurship. Our model does not incorporate indirect investment since there is no mechanism to insure repayment.

Capital movements in the form of portfolio investment have, however, become increasingly important to less developed countries. Implicit in this form of lending is a set of penalties for nonrepayment other than the ones we consider here. An important penalty may be exclusion from future participation in international capital markets. Elsewhere (Eaton and Gersovitz, 1981) we analyze financial market equilibrium in which the penalty of default is loss of future ability to borrow.

We could have incorporated similar considerations into the current analysis. For simplicity, however, we focus on a single period of what is a repeated process in the relationship between a host country and foreign investors. In contrast with our earlier work we do not consider explicitly the effect of an expropriation on the host country's ability to attract foreign capital in the future. This exclusion is justified if the host country has a high discount rate or if it cannot acquire a reputation, perhaps because its government changes frequently. Alternatively, we can 
incorporate the loss of future investment suffered by an expropriation into a general penalty consequent upon expropriation, the effects of which we do analyze here.

Oir model does assume, however, that investors act to protect their reputations in punishing expropriation: as a consequence of expropriation firms withdraw their managerial services or impose other penalties, such as an embargo on future investment in the country. An assumption of this sort is essential for the existence of an equilibrium with any capital movement at all. If investors cannot develop a reputation for punishing expropriators they have no incentive, ex post, to impose a penalty. Host countries would always expropriate, so that potential investors would never invest abroad. 
2. A Simple Model of Foreign Investment with Potential Expropriation

Consider an economy producing a single output (Q) using inputs of

. labor ( $\mathrm{L}$ ), capital (K) and managerial services (H) where

$$
\text { (2.1) } \quad Q=F(K, H, L)
$$

$F_{i}>0, F_{i i}<0$. The production function $F()$ exhibits constant returns to scale. The endowments of each factor possessed by the country are: $\bar{I}$, $\overline{\mathrm{K}}$ and $\overline{\mathrm{H}}$. t.t the time of foreign investment, capital and managers are completely robile between countries while workers are entirely immobile. Thus $L=\bar{L}$ while $K$ and $H$ exceed $\bar{K}$ and $\bar{H}$ by the amounts of foreign investmrat in capital and foreign transfer of managerlal skills respectively. lie focus only on situations in which $\mathrm{K}>\overline{\mathrm{K}}$ and $\mathrm{H}>\overline{\mathrm{H}}$. If $\mathrm{K}<\overline{\mathrm{K}}$ the economy we consider is a capital exporter, so that its expropriation of foreign capital is not an issue. ${ }^{2}$ If $\mathrm{K}>\overline{\mathrm{K}}$ while $\mathrm{H}<\overline{\mathrm{H}}$ the host country has nothing to lose from expropriation, since it is not importing foreign managers. In this case the host country would expropriate any amount of foreign capital. Investors will then find no amount of investment worthwhile so that $\mathrm{K} \leq \overline{\mathrm{K}}$.

The country is small in the international economy facing a gross rate of return on capital, I, and a managerial reward, $s$, given by world markets. Foreign investors borrow investment funds from the world capital market at cost $(r-1)$ and must repay the principal plus income whether or not 
expropriation occurs .

Profits of foreign investors if expropriation does not occur $\left(\pi^{N}\right)$ are (2.2a) $\quad \Pi^{N}=F(K, H, \bar{L})-Y^{N}-r(K-\bar{K})-s(H-\bar{H})$.

Here $Y^{N}$ denotes payment to the host country, its national income, if expropriation does not occur. If expropriation does occur, foreign managerial services are withdrawn, are no longer employed and need not be paid. Further, no payments need be made to host country factors. However, firms must still pay foreign lenders the value of their capital plus income. Thus, if expropriation occurs, the foreign investors receive profits $\left(\Pi^{E}\right)$ of (2.2b) $\quad \pi^{E}=-r(K-\bar{K})$.

If expropriation occurs, the host country takes over all production of of $Q,{ }^{3}$ and receives national income $\left(Y^{E}\right)$ of (2.3) $\quad Y^{E}=F(K, \bar{H}, \bar{L})$.

Expropriation is optimal if $\mathrm{Y}^{\mathrm{E}}>\mathrm{Y}^{\mathrm{N}}$ and not otherwise. The borderline condition $Y^{N}=Y^{E}$ defines a relationship between $Y^{N}$ and $K$ via (2.3) which we name the $\mathrm{EE}$ curve. For a given $\mathrm{Y}^{\mathrm{N}}$, investment in excess of the corresponding level of $\mathrm{K}$ on the EE curve implies expropriation. The slope of this curve is

(2.4) $\left.\quad \frac{d Y^{N}}{d K}\right|_{E E}=F_{K}(K, \bar{H}, \bar{L})>0$.

In the absence of expropiation profits are $\pi^{N}$ given by $(2.2 a)$. We assume that competition among potential investors guarantees $F_{H}=s$ and that $\mathrm{Y}^{\mathrm{N}}$ is such that

(2.5) $\quad \pi^{N}=0$ 
We discuss how the host country might extract $\mathrm{Y}^{\mathrm{N}}$ below. Equation (2.5) defines a second relationship between $Y^{N}$ and $K$. This is the II curve and has slope

$$
\left.\frac{d Y^{N}}{d K}\right|_{I I}=F_{K}(K, \hat{H}, \bar{L})-I
$$

where $\hat{\mathrm{H}}$ is given by

$$
F_{H}(K, \hat{H}, \bar{L})=s \quad \text {. }
$$

We define $\hat{\mathrm{K}}$ as the level of $K$ such that

$$
F_{K}(\hat{K}, \hat{H}, \bar{L})=r
$$

1.e., the level of $K$ that would obtain under perfect capital and managerial mobility with no threat of expropriation. On the usual assumption that $F_{\mathrm{KK}} F_{\mathrm{HH}}-F_{\mathrm{KH}}^{2}>0$, the II curve is upward sloping for $\mathrm{K}<\hat{\mathrm{K}}$ and downward sloping for $K>\hat{K}$.

The EE and II curves are 1llustrated in Figure 2.1. All points below the EE curve represent situations of expropriation. If these curves intersect only to the left of $\overline{\bar{R}}$, the EE curve lies everywhere about the II curve for $K>\bar{K}$ and no foreign investment is possible. Any investment would be expropriated. If the EE curve intersects the II curve anywhere to the right of $\hat{K}$, then the country obtains maximum income of $\hat{Y}^{N}$ since the point $\left(\hat{\mathrm{K}}, \hat{\mathrm{Y}}^{\mathrm{N}}\right.$ ) lies above the EE curve. In this case the expropriation constraint is not binding. An example of this situation is given by an $F()$ which is Cobb Douglas and an $\overline{\mathrm{H}}=0$. In this case, $\mathrm{Y}^{E}=0$ since output cannot be produced without $\mathrm{H}$.

If the EE curve cuts the II curve between $\bar{K}$ and $\hat{K}$ but not to the 
right of $\hat{\mathrm{K}}$ then the expropriation constraint is binding. Equilibrium is determined at a point such as $\left(\tilde{\mathrm{K}}, \tilde{\mathrm{Y}}^{\mathrm{N}}\right)$. It is possible that the EE curve cuts the II curve more than once between $\overline{\mathrm{K}}$ and $\hat{\mathrm{K}}$ with no intersection to the right of $\hat{\mathrm{K}}$. In this case we assune that the host obtains the highest possible income. At this point the EE curve cuts the II curve from below. 4 Thus, at an equilibrium where the expropriation constraint determines the country's capital stock ${ }^{5}$

(2.8a) $\quad F_{K}(K, \bar{H}, \bar{L})>F_{K}(K, \hat{H}, \bar{L})-r$

(2.8b) $\quad \pi^{N}=0$

(2.8c) $\quad \mathrm{Y}^{\mathrm{N}}=\mathrm{Y}^{\mathrm{E}}$

The remainder of this section focuses on this type of equilibrium.

When the threat of expropriation is binding, $\mathrm{K}<\hat{\mathrm{K}}$ as given by $(2.7)$ and the marginal product of capital exceeds the world interest rate, $r$. Thus if all domestic factors are paid their marginal products, foreign managers are paid their marginal product and foreign capital is paid $r$, Euler's theorem implies that the value of total output will exceed the sum of factor payments by a wedge $\left(F_{K}(K, \hat{H}, \bar{L})-r\right)(K-\bar{K})$. We assume that because of competition among potential investors this wedge accrues to the host country.

There are a number of mechanisms whereby the host country could extract this wedge. One would be the imposition of a lump-sum tax on foreign investors in this amount. Such a tax would allow the host country to maximize the benefits from foreign investment given that it cannot foreswear expropriation. An equivalent tax would be a tax on capital $\left(t_{K}{ }^{*}\right)$ such that 
$\left(1-t_{K}^{*}\right) F_{K}(K, \hat{H}, \bar{L})=r$ at the point where the EE and II curves intersect. 6 Taxes on foreign capital in LDC's are in fact quite common and can be justified if forelgn investment is already constrained by the threat of expropriation. 7

Maintaining the assumption that the host country does receive the rent on foreign investment, we now analyse the effects of changes in various exogenous variables on the equilibrium level of investment and on national income when the threat of expropriation is binding.

First consider an increase in $\overline{\mathrm{K}}$, the supply of nationally-owned capital. This change shifts the II curve up by an amount $r$, raising the equilibrium levels of $\mathrm{Y}^{\mathrm{N}}$ and $\mathrm{K}$. If the threat of expropriation were not binding, $K$ would remain at $\hat{K}$ while $\hat{Y}^{N}$ would rise by $r$. When the threat of expropriation determines $K$, however, an increase in national capital raises the total level of capital and raises national income by more than $r$.

An increase in $\overline{\mathrm{H}}$ shifts the II curve up by $s$ and the EE curve up by $F_{H}(K, \bar{H}, \overline{\mathrm{L}})>s$. Equilibrium income rises by less than $s$ and may even fall. The level of foreign investment falls. With more national managers expropriation is, ceteris paribus, more desirable. This effect leads to a reduction in foreign investment and in the total capital stock.

An increase in $\overline{\mathrm{L}}$ shifts the II curve up by $F_{L}(K, \hat{\mathrm{H}}, \overline{\mathrm{L}})$ and the $E E$ curve up by $F_{L}(K, \bar{H}, \bar{L})$. Since at equilibrium $\hat{H}>\bar{H}$, income rises by more or less than $F_{L}(K, \hat{A}, \bar{L})$ and foreign investment rises or falls as $F_{L H} \gtrless 0$. If labor and managers are complements an increase in $\overline{\mathrm{L}}$ increases the benefit accruing to the host from the presence of foreign managers and reduces the incentive to expropriate.

An increase in $r$ has no effect on the EE curve but shifts the II curve 
down by $(K-\bar{K})$. The equilibrium level of $K$ falls, as does the equilibrium level of $Y^{N}$ which falls by more than $K-\bar{K}$, the amount by which $\hat{Y}^{N}$ falls. An increase in $s$ has no effect on the EE curve (at the equilibrium (point) but shifts the II curve down by $\mathrm{H}-\overline{\mathrm{H}}$. Again the equilibrium level of $\mathrm{K}$ falls, as does the equilibrium level of $\mathrm{Y}^{\mathrm{N}}$, which falls by more than $\mathrm{H}-\overline{\mathrm{H}}$, the amount by which $\hat{\mathrm{Y}}^{\mathrm{N}}$ falls.

When the threat of expropriation is binding, increases in the international prices of imported factors have a larger negative effect on national income than otherwise. The reason is that, at higher prices of these factors, only a lower level of compensation of national factors is compatible with competitive equilibrium. At a given level of foreign investment, expropriation would be optimal. Hence foreign investment is reduced.

If a penalty $(P>0)$ is imposed in case of expropriation equation (2.3) can be modified to $\left(2.3^{\prime}\right) \quad Y^{E}=F(K, \bar{H}, \bar{L})-P$

An increase in $P$ leaves the II curve unchanged but shifts the EE curve down, increasing foreign Investment and national income. Thus a penalty for expropriation can make a capital importer better off.

Finally we note the distributional consequences of the threat of expropriation. For analytic simplicity we assume that the tax implicit in a binding threat of expropriation accrues to the government while the three national factors earn their marginal products. In relation to a situation of perfect capital mobility, capital gains (by $\left.\left(F_{K}(K, \hat{H}, \bar{L})-r\right) \bar{K}\right)$ while labor 1oses. National managers earn $s$ independent of the level of forelgn investment and are unaffected. In Section 7, where we present a model where the act of expropriation can actually occur, we discuss the effects of an expropriation itself on the distribution of income among factors. 


\section{Implications for Project Evaluation}

In the previous section, national factor supplies $\overline{\mathrm{K}}, \overline{\mathrm{L}}$ and $\overline{\mathrm{H}}$, were exogenous. From a longer-run perspective, however, the supplies of capital and managerial services are determined by national decisions to invest in physical and human capital. In this section we use the model to examine the implications of expropriation for optimal investment strategies.

The model implicitly determines national income, $Y$, in terms of the national endowments of factors so that we may write $Y=Y(\bar{K}, \bar{H}, \overline{\mathrm{L}})$. Consider a two-period decision. In the first period resources are allocated toward producing physical and human capital. The economy initially has a work force of size $\mathrm{N}$ and training for management requires withdrawal from he labor force for one period, denoted period 0 . Consumption in the $f$ rst period is therefore

$$
c_{0}=I(\overline{\mathrm{N}}-\overline{\mathrm{H}})-\overline{\mathrm{K}}
$$

where $I$ is the period 0 production function for comoditics. Preferences are a function of period 0 consumption and period 1 natioral income, $U\left(C_{0}, Y\right)$. Then $\overline{\mathrm{H}}$ and $\overline{\mathrm{K}}$ will be chosen so that

$$
-\mathrm{U}_{1} \mathrm{I}^{\prime}+\mathrm{U}_{2} \mathrm{Y}_{\overline{\mathrm{H}}}=0
$$

At an expropriation-constrained equilibrium described by (2.8) and the EE and II curves

$$
\text { (3.4) } \quad Y_{\overline{\mathrm{K}}} \equiv \frac{\mathrm{dY}}{\mathrm{d} \overline{\mathrm{K}}}=\left(\mathrm{F}_{\mathrm{K}}(\mathrm{K}, \hat{\mathrm{H}}, \overline{\mathrm{L}})-\mathrm{r}\right)\left[\frac{\mathrm{r}}{\mathrm{F}_{\mathrm{K}}(\mathrm{K}, \overline{\mathrm{H}}, \overline{\mathrm{L}})+\mathrm{r}-\mathrm{F}_{\mathrm{K}}(\mathrm{K}, \hat{\mathrm{H}}, \overline{\mathrm{L}})}\right]+\mathrm{r}
$$


(3.5) $\quad Y_{\overline{\mathrm{H}}} \equiv \frac{\mathrm{dY}}{\mathrm{d} \overline{\mathrm{H}}}=\left(F_{\mathrm{K}}(\mathrm{K}, \hat{\mathrm{H}}, \overline{\mathrm{L}})-\mathrm{r}\right) \frac{\mathrm{dK}}{\mathrm{d} \overline{\mathrm{H}}}+s$.

Consider first the social return to national capital, $\mathrm{Y}_{\overline{\mathrm{K}}} \cdot{ }^{-}$From $(2.8 \mathrm{a})$, : at an equilibrium, the coefficient of $F_{K}(K, \hat{H}, \bar{L})-r$ is positive. Thus, since $F_{K}(K, \hat{H}, \bar{L})-I>0$, the soctal return to national capital exceeds the world interest rate $I$. Furthermore, if managers and capital are complements, $F_{K}(K, \bar{H}, \bar{L})<F_{K}(K, \hat{H}, \bar{L})$. In this case $Y_{\bar{K}}>F_{K}(K, \hat{H}, \bar{L})$; i.e., the social return to national capital exceeds its marginal physical product. Conversely, if $K$ and $H$ are substitutes, $F_{K}(K, \bar{H}, \bar{L})>F_{K}(K, \hat{H}, \bar{L})$ and the return to capital lies between the domestic marginal physical product and the world interest rate. In the first case increasing the capital stock increases the productivity of managers, thereby reducing the incentive to expropriate. Conversely in the second case.

An increase in the supply of national managerial services, on the other hand, Increases incone by less than the world reward to managerial services, $s$, which equals the domestic marginal product of managerial services. By reducing reliance on foreign managerial services, an increase in $\bar{H}$ reduces the avallability of forelgn capital. This effect way operate to the extent that $\mathrm{Y}_{\overline{\mathrm{H}}}<0$.

In summary, when the threat of expropriation is binding it is optimal to deviate from both marginal product and world price rules in investment decisions. As long as capital and managers are complements both rules tend to understate the marginal social product of capital and to overstate the marginal social product of managers. 


\section{Investment by Monopolistic Investors}

In Section 2 we assumed that investors were perfectly competitive in that the host country could extract a payment that drove profits to zero. Facing a large number of potential investors, the host would only accept investment projects yielding zero profits to the investor. We now turn to the case in which the foreign investor is a monopolist vis-a-vis a large number of host countries, but remains competitive in world markets for capital and managerial services. ${ }^{8}$ The threat of expropriation nevertheless exists.

As before, if the host country expropriates, it earns an income of $\mathrm{Y}^{\mathrm{E}}=\mathrm{F}(\mathrm{K}, \overline{\mathrm{H}}, \overline{\mathrm{L}})$. The monopolistic investor must pay the host country at least this amount to preclude expropriation, but has no reason to pay more. Thus profits are given by

(4.1) $\quad \Pi^{N}=F(K, H, \bar{L})-F(K, \bar{H}, \bar{L})-r(K-\bar{K})-s(H-\bar{H})$.

First order conditions for profit maximization imply

$$
\Pi_{K}=F_{K}(K, \hat{H}, \bar{L})-F_{K}(K, \bar{H}, \bar{L})-r=0
$$

$$
\Pi_{H}=F_{H}(K, \hat{H}, \bar{L})-s=0
$$

For the second-order condition to be satisfied we require that $\mathrm{F}_{\mathrm{KK}}(\mathrm{K}, \hat{\mathrm{H}}, \overline{\mathrm{L}})$ $\mathrm{F}_{\mathrm{KK}}(\mathrm{K}, \overline{\mathrm{H}}, \overline{\mathrm{L}})<0$, i.e., $\mathrm{F}_{\mathrm{KKH}}<0$. If it is not satisfied anywhere, then $\mathrm{K}=\overline{\mathrm{K}}$ and no foreign investment occurs. As in the competitive case, the foreign investor equates the marginal product of managerial services to the world salary but maintains a domestic product of capital in excess of the world interest rate.

Subsituting (4.2) and (4.3) Into (4.1) and applying Euler's theorem yields 
$(4.4)$

$$
\begin{aligned}
\Pi & =\left\{F_{L}(K, \hat{H}, \bar{L})-F_{L}(K, \bar{H}, \bar{L})\right\} \bar{L}+\left\{F_{K}(K, \hat{H}, \bar{L})-F_{K}(K, \bar{H}, \bar{L})\right\} \bar{K} \\
& +\left\{F_{H}(K, \hat{H}, \bar{L})-F_{H}(K, \bar{H}, \bar{L})\right\} \bar{H}
\end{aligned}
$$

as an alternative expression for profits. Monopoly profits are the difference between national factor incomes at actual marginal productivities and the marginal productivities that would obtain if expropriation were to occur.

Consider again a penalty $P$ that the host country would suffer if it should expropriate. In this case the host country will receive only

$$
Y^{E}=F(K, \bar{H}, \bar{L})-P
$$

in the event of expropriation. Note that the same $k$ is chosen by the monopolist since $P$ does not alter the first order conditions (4.2) and (4.3). However, the investor need only pay the amount $Y^{E}$ to preclude expropriation. The existence of the penalty increases monopoly profits and reduces national income even though expropriation does not take place, in contrast with the competitive case, where the penalty raises national income. Given the production function $F()$, the monopolist will always invest less than competitive investors. When (4.2) is satisfied, (4.1) is positive. Since $\pi_{K}<0$ for values of $K$ greater than the level of monopoly investment, the level of $K$ which satisfies $\Pi=0$ is greater than the level that satisfies $\pi_{\mathrm{K}}=0$. 
5. Potential Expropriation and the Distortion of Technology

In Section 2 the threat of expropriation was shown to imply a distortion in factor use. Too little capital was invested by foreigners so that the economy's capital-labor ratio $(\mathrm{K} / \mathrm{L})$ was below the unconstrained optimum. Other forms of distortion may be consequences of a threat of expropriation. For instance, Magee (1977) discusses expenditures foreign investors may make to conceal the nature of their production process.

A very general formulation of this notion is to assume that the firm's profit in the absence of expropriation is given by

$$
\Pi^{N}=F(K, H, \bar{L}, \gamma)-s(H-\bar{H})-r(K-\bar{K})-C(K, H, \bar{L}, \gamma)-Y^{N}
$$

where $\gamma$ is a parameter of the production function and $C(\cdot)$ is the cost over and above any effect on $F()$ of choosing a particular value of $\gamma$. Increases in $\gamma$ increase $\mathrm{C}$, i.e., $\partial \mathrm{C} / \partial \gamma>0$. In the event of expropriation, national income is

$$
Y^{E}=J(K, \bar{H}, \overline{\mathrm{L}}, \gamma)
$$

where $J(\cdot)$ is the country's production function after expropriation. 9

Once the possibility of distorting technology is introduced, two conclusions from the previous analysis need not obtain. First, the level of investment occurring in competitive equilibrium under a threat of expropriation may exceed that obtaining under perfect capital mobility. Second, a monopolistic investor may invest more than the competitive equilibrium level of capital.

To establish these propositions we define

$$
G(K, \gamma) \equiv F(K, \hat{H}, \bar{L}, \gamma)-C(K, \hat{H}, \bar{L}, \gamma)-s(\hat{H}-\bar{H})
$$


where, since $H$ is mobile ex post, $\hat{H}$ is defined implicitly by $F_{H}-C_{H}-s=0$. For simplicity we consider a technology in which $\gamma$ assumes a value of either 0 or 1 , and assurne that $G(K, 0)>G(K, 1)$ for all $k$.

In the absence of an expropriation option, competitive investors will choose $\gamma=0$ and set $k=\hat{k}_{0}$, where $G_{k}\left(\hat{k}_{0}, 0\right)=r$. If however,

$$
J\left(\hat{\mathrm{K}}_{0}, 0\right)>G\left(\hat{\mathrm{K}}_{0}, 0\right)-r\left(\hat{\mathrm{K}}_{0}-\overline{\mathrm{K}}\right)
$$

where we suppress the constants $\overline{\mathrm{H}}$ and $\overline{\mathrm{L}}$ in $\mathrm{J}()$, investment at a level $\hat{\mathrm{K}}_{0}$ would lead to expropriation. If $\gamma=0$ investment would occur only until $\mathrm{K}=\mathrm{K}_{0}^{*}<\hat{\mathrm{K}}_{0}$ where $\mathrm{K}_{0}^{*}$ satisfies $(5.4)$ with equality.

Consider now the case where $\gamma=1$. Define $\hat{K}_{1}$ as the level of $K$ satisfying $G_{K}\left(\hat{K}_{1}, 1\right)=r_{0}$ If

$$
J\left(\hat{\mathrm{K}}_{1}, 1\right)<G\left(\hat{\mathrm{K}}_{1}, 1\right)-r\left(\hat{\mathrm{K}}_{1}-\overline{\mathrm{K}}\right)>J\left(\mathrm{~K}_{0}^{*}, 0\right)
$$

then, by choosing $\gamma=1$ and investing $\hat{\mathrm{K}}_{1}$, competitive investors can provide the host country a higher national income than by choosing $\gamma=0$ and investing $k_{0}^{*}$. If, instead, the first inequality of (5.5) is not satisfied, investors will provide only $k_{1}^{*}$ capital if $\gamma=1$, where $k_{1}^{*}$ satisfies

$$
J\left(K_{1}^{*}, 1\right)=G\left(k_{1}^{*}, 1\right)-r\left(k_{1}^{*}-\bar{K}\right)
$$

Nevertheless, if

$$
J\left(k_{1}^{*}, 1\right)>J\left(k_{0}^{*}, 0\right)
$$

competitive investors can still provide the host country a higher income by choosing $\gamma=1$ and rationing investment at $x_{1}^{*}$. Nothing precludes the possibility that $\hat{\mathrm{K}}_{1}>\hat{\mathrm{K}}_{0}$ or that $\mathrm{K}_{1}^{*}>\hat{\mathrm{K}}_{0}$. In these cases more capital is installed because the threat of expropriation is binding when the first best $(\gamma=0)$ is used. This possibility requires, however, that 


$$
G_{K}(K, 1)>G_{K}(K, 0)
$$

1.e., that the distortion of technology augment the marginal product of capital to the investor.

To establish the second proposition assume that, in fact, $J\left(K_{0}^{*}, 0\right)>$ $\mathrm{J}\left(\mathrm{K}_{1}^{*}, 1\right)$. In this case, under competition, there will be no distortion of technology and $\gamma$ will equal 0 . If, instead, there is a single monopolistic investor his profits will be

$$
\text { (5.9) } \max _{\gamma=0,1}\left[G\left(k_{\gamma}^{m}, \gamma\right)-J\left(k_{\gamma}^{m}, \gamma\right)-r\left(k_{\gamma}^{m}-\bar{k}\right)\right]
$$

where $k_{\gamma}^{m}$ is defined implicitly by the condition:

$$
G_{K}(K, \gamma)-J_{K}(K, \gamma)-r=0, \quad \gamma=0,1
$$

If $J(K, 0) \gg J(K, 1)$, then $(5.9)$ is likely to be attained at $\gamma=1$. If, again, $G_{K}(K, 1)>G_{K}(K, 0)$ while, in addition, $J_{K}(K, 1)<J_{K}(K, 0)$, then $\mathrm{K}_{l}^{\mathrm{m}}>\hat{\mathrm{K}}_{0}>\mathrm{K}_{0}^{*}$ is possible. The monopolist may find that, by distorting his technology in a way that increases the marginal product of capital to him, he reduces the usefulness of his capital stock to a potential expropriator, thereby reducing required compensation to the host country. Because the marginal product of capital is greater with this distortion, he invests more than competitive investors who, in this case, do not install a distorted technology.

The distortion of technology, in terms of its effects on the welfare of the host country, is analogous to an increase in the penalty $P$ incumbent on the host in the event of default. When potential investors are competitive, the host country benefits from the ability of investors to distort technology. The ability of a monopolistic investor to distort technology, however, acts to the host country's detriment. 


\section{Optimal Investment in Risky Projects}

In Sections 2 to 5 foreign investment was riskless. Frequently, however, foreign investors engage in risky activities bearing much of this risk. In Expropriating such activities the host assumes the risk inherent in these activities.

We assume that domestic production (Q) is given by the function

$$
Q=\theta F(K, L),
$$

$\theta$ is a random variable; in this section we abstract from managerial services. National endowments of capital and labor are $\overline{\mathrm{K}}$ and $\overline{\mathrm{L}}$. Capital is mobile across borders before the Investment takes place while labor is not. Capital is in place at the time $\theta$ is known and cannot be withdrawn. Expropriation must also be chosen before the true value of $\theta$ is known. Investors are competitive and either risk neutral or consider the risk completely diversifiable.

In the absence of expropriation, host income is $Y^{N}$ regardless of $\theta$. If expropriation occurs, national income $\left(Y^{E}\right)$ depends on $\theta$ :

$$
\text { (6.2) } \quad \mathrm{Y}^{\mathrm{E}}=\theta \mathrm{F}(\mathrm{K}, \overline{\mathrm{L}})
$$

Expropriation will be optimal if $E\left[U\left(Y^{E}\right)\right]$ exceeds $U\left(Y^{N}\right)$ and not otherwise where $U(\cdot)$ is the host's utility of income. Since $E\left[U\left(Y^{E}\right)\right]$ increases in $K$, the condition

$$
E\left[U\left(Y^{E}\right)\right]=\dot{U}\left(Y^{N}\right)
$$

Implicitly defines a level of $K$, denoted $K^{*}\left(Y^{N}\right)$ such that $K>K^{*}$ implies that expropriation is optimal and not otherwise. Note that $K^{\star \prime}\left(Y^{N}\right)>0$. If expropriation occurs foreign investors will earn profits of (6.4) $\quad \pi^{E}=-r(K-\bar{K})$ 
assuming, as before, that foreign sources of capital must be paid regardless. If expropriation does not occur then profits are

$$
\Pi^{N}=\theta F(K, L)-r(K-\bar{K})-Y^{N}
$$

Firms maximize expected profits. If $K$ is less than $K^{*}$ then investment occurs until

$$
E\left[\theta F_{K}(K, \bar{L})-r\right]=0
$$

Denote $\hat{k}$ by the level of $K$ satisfying (6.6).

Competition among investors and taxation of the type discussed in Section 2 will raise $Y^{N}$ to the point where

$$
\text { (6.7) } \quad E\left[\theta F(K, \bar{L})-Y^{N}-I(K-\bar{K})\right]=0 \text {. }
$$

Denote the level of $\mathrm{Y}^{\mathrm{N}}$ satisfying $(6.7)$ at $\mathrm{K}=\hat{\mathrm{K}}$ by $\hat{\mathrm{Y}}^{\mathrm{N}}$. If $\hat{\mathrm{K}}<\mathrm{K}^{*}\left(\hat{\mathrm{Y}}^{\mathrm{N}}\right)$ then $\hat{K}$ defines an equilibrium level of total investment and $\hat{Y}^{N}$ an equilibrium level of national income. At this equilibrium the threat of expropriation is not binding. If however $\hat{\mathrm{K}}>\mathrm{K}^{*}\left(\hat{\mathrm{Y}}^{\mathrm{N}}\right)$ investment at a level of $\hat{\mathrm{K}}$ will lead to expropriation and the equilibrium level of investment will be constrained.

We depict the resulting equilibrimo in Figure 6.1 . Values of $K$ and $Y^{N}$ consistent with competition in international capital markets, i.e., satisfyIng (6.7), are 1llustrated by the curve II. Values satisfying the no expropriation condition with strict equality, 1.e.,

(6.8) $\quad E\{U[\theta F(K, \tilde{L})]\}=U\left(Y^{N}\right)$

are 11lustrated by the curve EE.

The slope of II is given by

$$
\text { (6.9) }\left.\quad \frac{d Y^{N}}{d K}\right|_{I I}=E\left(\theta F_{K}-I\right) \text {. }
$$


positive for $\mathrm{K}<\hat{\mathrm{K}}$ and negative for $\mathrm{K}>\hat{\mathrm{K}}$. Thus the II curve achieves a maximum at $\hat{\mathrm{K}}$ where it is satisfied by $\hat{\mathrm{Y}}^{\mathrm{N}}$. The EE curve has slope

$$
\left.\frac{d Y^{N}}{d K}\right|_{E E}=\frac{\dot{E}\left\{U^{\prime}[\theta F(K, L)] \theta F_{K}\right\}}{U^{P}\left(Y^{N}\right)}>0 .
$$

The expected output if no investment occurs is

$$
\text { (6.11) } \quad \overline{\bar{Y}}^{N} \equiv E(\theta) F(\bar{K}, \bar{L})
$$

This is the amount foreign investors are willing to pay to produce in the host country without investing any foreign capital. We define $\bar{Y}^{N}$ by the relationship

(6.12) $\quad E\{U[\theta F(\bar{K}, \bar{L})]\}=U\left(\bar{Y}^{N}\right)$,

1.e., $\overline{\mathrm{Y}}^{\mathrm{N}}$ is the amount investors must pay the host for the right to use domestic factors if they make no investment themselves.

If $U$ is concave then $\overline{\mathrm{Y}}^{\mathrm{N}}<\overline{\overline{\mathrm{Y}}}^{\mathrm{N}}$. In this case the EE and II curves will cross to the right of $\overline{\mathrm{K}}$, 1.e., there will exist one equilibrium compatible with: (1) competitive international capital markets, (2) no expropriation and (3) a positive level of foreign investment. Thus if the host is risk averse while investors are risk neutral, some investment will occur. If the $E E$ and II curves cross to the right of $\hat{k}$ the equilibrium will be characterized by $\hat{\mathrm{K}}$ and $\hat{\mathrm{Y}}$ and the threat of expropriation is not binding. If the curves cross only to the left of $\hat{\mathrm{K}}$ the competitive equilibrium levels of $K$ and $Y$ are constrained by the threat of expropriation. If the EE curve cuts the II curve more than once, we assume, as before, that the equiIibrium with the highest $\mathrm{Y}^{\mathrm{N}}$ obtains. We next determine the effects of increases in risk and in $E(\theta), \bar{k}, \bar{L}$ and $r$ on the equilibrium levels of $K$ and $Y$ when the EE curve cuts the II curve from below and the threat of expropriation is binding $(K<\hat{K})$. 
First, if output becomes more uncertain, a risk averse host country is less willing to expropriate. A lower level of compensation $\mathrm{Y}^{\mathrm{N}}$ is required to forestall expropriation of a given capital stock. The EE curve shifts down. Risk neutral investors do not require a higher expected return, so the II curve does not shift. The equilibrium values of $\mathrm{Y}^{\mathrm{N}}$ and $\mathrm{K}$ rise. Paradoxically, then, an increase in the riskiness of investment can actually increase national income and national welfare by reducing the incentive to expropriate and attracting foreign investment.

Given $K$, an increase in $E(\theta)$ shifts both the $E E$ and II curves up by an amount $F$. Income, but not the level of foreign investment, rises.

An increase in $\overline{\mathrm{L}}$ shifts the II curve up by an amount

(6.13) $\left.\quad \frac{d Y^{N}}{d \bar{L}}\right|_{I I}=E(\theta) F_{L}$

and the EE curve by

(6.14) $\left.\frac{d Y^{N}}{d \bar{L}}\right|_{E E}=\frac{E\left(U^{\prime} \theta F_{L}\right)}{E\left(U^{\prime}\right)}=E(\theta) F_{L}+\frac{\operatorname{cov}\left(U^{\prime}, \theta F_{L}\right)}{E\left(U^{\prime \prime}\right)}$.

If the host country is risk averse $U^{\prime}$ is a decreasing function of $\theta$ and the second term in the far right version of (6.14) is negative. Hence the II curve shifts up by more than the EE curve. $Y^{N}$ rises by more than $E(\theta) F_{L}$ and foreign investment rises. Because an increase in $\bar{L}$ raises the riskiness as well as the level of output the host country is able to accept more capital.

An increase in $\overline{\mathrm{K}}$ or a reduction in $r$ continues to increase income. As in the certainty model, this effect is larger when the threat of expropriation is binding relative to a situation of perfect capital mobility. 


\section{Investment with Stochastic Expropriation}

In previous sections we have presented models in which expropriation never actually occurs. In a deterministic context, or in a context in which the expropriation decision must occur before any randomess is resolved, expropriation can be predicted exactly, and rational, fully-informed investors will not make investments that will be expropriated. If, however, some random process affecting the desirability of expropriation is resolved between the time of the investment and the expropriation decision, investments may be expropriated. Investors make such investments accepting this risk.

Although the investigation of a model with stochastic expropriation is considerably more difficult than the preceding analysis it is crucially important to an understanding of the expropriation issue. To illustrate this phenomenon, consider again the model developed in section 2, but assume that the supply of national managers, $\overline{\mathrm{H}}$, is given by a function $\overline{\mathrm{H}}(\theta)$ increasing. in $\theta$, where $\theta$ is a random variable uniformly distributed on $(0,1)$. $\theta$ is not known when investment takes place but is revealed before the expropriation decision. A number of other variables could be random. Introducing uncertainty in the supply of national managers provides one simple means of illustrating some aspects of stochastic expropriation.

National income, if expropriation does not take place, is given by

$$
\text { (7.1) } \quad \mathrm{Y}^{\mathrm{N}}(\theta)=\mathrm{r}^{\mathrm{d}} \overline{\mathrm{K}}+\mathrm{w} \overline{\mathrm{L}}+\mathrm{s} \overline{\mathrm{H}}(\theta)=\mathrm{F}(\mathrm{K}, \hat{\mathrm{H}}, \overline{\mathrm{L}})-\mathrm{F}_{\mathrm{K}}(\mathrm{K}-\overline{\mathrm{K}})-\mathrm{s}(\hat{\mathrm{H}}-\overline{\mathrm{H}})
$$

where $\mathrm{r}^{\mathrm{d}}$ is the interest rate paid national capital, $w$ the wage and other variables are defined in section 2. The third part of equation (7.1) follows from Euler's theorem and our assumption that national factors receive their marginal products. In contrast to the deterministic case, such payments will exhaust product, as we show below. The profits of foreign firms, if 
expropriation does not occur, are, as before,

$$
\pi^{N}=F(K, \hat{H}, \bar{L})-Y^{N}-r(K-\bar{K})-s(\hat{H}-\bar{H})
$$

In the event of expropriation, however, national income becomes

$$
Y^{E}(\theta)=G(K, \bar{H}(\theta), \hat{H}, \bar{L})
$$

where

$$
G(K, \bar{H}(\theta), \hat{H}, \bar{L}) \equiv \max [F(K, \bar{H}(\theta), \bar{L}), F(K, \hat{H}, \bar{L})+s(\bar{H}-\hat{H})]
$$

since it is now possible that $\overline{\mathrm{H}}(\theta)>\hat{\mathrm{H}}$ for high values of $\theta$. This possibility of the host exporting managerial services was ruled out in the deterministic model of section 2. Profits are simply, as before,

$$
\text { (7.5) } \quad \Pi^{E}=-r(K-\bar{K}) \text {. }
$$

Expropriation becomes optimal, then, when $\mathrm{Y}^{\mathrm{E}}>\mathrm{Y}^{\mathrm{N}}$ and not otherwise. Note that both $Y^{E}$ and $Y^{N}$ are increasing in $\theta$, and that

$$
\text { (7.6) } \quad \frac{d Y^{N}}{d \theta}=s \bar{H}^{\prime}
$$

while

$$
\text { (7.7) } \quad \frac{d Y^{E}}{d \theta}=\left\{\max \left[F_{H}(K, \bar{H}(\theta), L), s\right]\right\} \bar{H} \text { ' }
$$

so that

$$
\frac{d Y^{N}}{d \theta} \leq \frac{d Y^{E}}{d \theta}
$$

1.e., as $\theta$ rises, expropriation becomes more desirable.

The value $\theta^{*}$ is defined by the condition

$$
\begin{aligned}
& \text { (7.8) } Y^{N}\left(\theta^{*}\right)=Y^{E}\left(\theta^{*}\right) \\
& \text { or } \theta^{*}=0 \text { if } Y^{E}(0)>Y^{N}(0) \text { or } \theta^{*}=1 \text { if } Y^{N}(1)>Y^{E}(1) \text {. }
\end{aligned}
$$

Expected profits are given by

$$
E(I)=\theta^{*}\left[F(K, \hat{H}, \bar{L})-r^{d} \bar{K}-s \hat{H}-w \bar{L}\right]-r(K-\bar{K}) .
$$


We assume that investors are atomistic, and take not only $r$ and $s$, but $\mathrm{r}^{\mathrm{d}}$, w and $\theta^{*}$ as given; individual investors invest too little to consider their investments to affect national factor prices or the probability of expropriation. Competition among investors implies zero expected profits

(7.10a) $E(\pi)=0$.

This condition, along with the assumption that national factors and foreign managers are paid their marginal products and Euler's theorem, implies that

(7.10b) $\quad \theta^{*} F_{K}-r=0 \quad($ if $K>0)$.

But this result is equivalent to the first order condition of $E(I)$ with respect to $\mathrm{K}$. In a situation of stochastic expropriation, the host need not impose a tax of $t_{K}^{*}$ to ensure zero expected profits - the probability of expropriation, $\left(1-\theta^{*}\right)$, plays an analogous role.

Together (7.8) and (7.10a), along with $r, s, \overline{\mathrm{K}}$ and $\overline{\mathrm{L}}$, determine equilibrium values of $\mathrm{K}, \mathrm{H}$ and $\theta^{*}$.

Using $F_{H}=s$ to determine $H$ implicitly and substituting into (7.8) and (7.10b) we obtain two equations in two unknowns, $\theta^{*}$ and K. Relationship (7.10b) gives values of $K$ and $\theta^{*}$ consistent with zero profits. We denote this locus the II curve. If $\theta^{*} \varepsilon(0,1)$ the II curve has slope.

$$
\left.\frac{\mathrm{d} \theta^{*}}{\mathrm{dK}}\right|_{\mathrm{II}}=\frac{-\theta^{*}\left(F_{\mathrm{KK}} F_{\mathrm{HH}}-F_{\mathrm{KH}}^{2}\right)}{\left(\mathrm{F}_{\mathrm{K}} F_{\mathrm{HH}}\right)}
$$

If $F$ is a well-behaved production function, the principal minors alternate in sign and $\mathrm{F}_{\mathrm{KK}} \mathrm{F}_{\mathrm{HH}}>\mathrm{F}_{\mathrm{HK}}^{2}$, implying that the II curve slopes upward. An increase in $\theta^{*}$ increases the expected return on capital, increasing $K$. The II curve is drawn in figure 7.1. At $\theta^{*}=0$ expropriation is almost certain and $\mathrm{K}=\overline{\mathrm{K}}$; no foreign Investment takes place. At the other extreme, if $\theta^{*}=1$ expropriation is almost certain not to occur, and $K=\hat{K}$, where 


$$
F_{K}(\hat{K}, \hat{H}, \bar{L})=\mathbf{r}
$$

defines the equilibrium value of $\mathrm{K}$.

Relationship (7.8) defines $\theta^{*}$ as another function of $\mathrm{K}$ and exogenous variables. We call it the EE curve. It has slope

$$
\left.\frac{d \theta^{*}}{d K}\right|_{E E}=\frac{F_{H H} G_{K}+\left(F_{H H} F_{K K}-F_{H K}^{2}\right)(K-\bar{K})}{F_{H H}\left(s-G_{H}\right) \bar{H}^{\prime}}
$$

which is ambiguous in sign. The ambiguity arises because an increase

in $\mathrm{K}$ raises income whether expropriation occurs or not.

In general we cannot say in which state income rises more.

Because of this ambiguity equilibria with higher levels of foreign investment may, ceteris paribus, be associated with a lower probability of expropriation.

Whatever the slope of the EE curve, however, it lies completely to the right of $\overline{\mathrm{K}}$ for $\theta^{*}<1$; at $\mathrm{K}=\overline{\mathrm{K}}, \mathrm{Y}^{\mathrm{N}} \geq \mathrm{Y}^{\mathrm{E}}$ for all values of $\dot{\theta}$. If $\mathrm{K}=\overline{\mathrm{K}}$, the host country gains no capital by expropriating but loses its ability to import managerial services. Consequently the threat of expropriation never prohibits foreign investment entirely.

The EE and II curves may cross several times as illustrated in Figure 7.1. Because $\theta^{*}$ tends to zero as $K$ tends to infinity, the last intersection of these two curves must have the EE curve cutting the II curve from above.

The expected value of the host's income, $E[Y(\theta)]$, is given by

$$
E(Y)=\int_{0}^{\theta^{*}} Y^{N}(\theta) d \theta+\int_{\theta}^{1} Y^{E}(\theta) d \theta
$$

Using (7.1), (7.8), (7.10b) and (7.11), it can be shown that

$$
\left.\frac{\mathrm{dE}(\mathrm{Y})}{\mathrm{d} \theta^{*}}\right|_{I I}=\left.\left[\frac{\theta^{*}\left(\mathrm{~F}_{\mathrm{KH}}^{2}-\mathrm{F}_{\mathrm{KK}} \mathrm{F}_{\mathrm{HH}}\right)(\mathrm{K}-\overline{\mathrm{K}})}{\mathrm{F}_{\mathrm{HH}}}+\int_{\theta^{*}}^{1} \mathrm{G}_{\mathrm{K}} \mathrm{d} \theta\right] \frac{\mathrm{dK}}{\mathrm{d} \theta^{*}}\right|_{I I}>0
$$

1.e., $E(Y)$ increases along the II curve. We assume, as before, that the 
host country ensures that the highest intersection of the EE and the II curves is chosen.

The local effects of increases in $\overline{\mathrm{K}}, \overline{\mathrm{L}}, E(\overline{\mathrm{H}}), \mathbf{r}$ and $s$-are determined by the effect of these changes on the positions of the II and EE curves:

First consider an increase in $\overline{\mathrm{K}}$. The II curve is unaffected while the EE curve shifts up. The equilibrium levels of $\theta^{*}$ and $k$ rise; i.e., total investment rises and the probability of default declines. As in the preceding models, national capital does not crowd out foreign capital one-for-one.

Secondly, if $\bar{L}$ increases the II curve shifts down (which follows from Euler's theorem applied to the marginal products of a constant return to scale production function) while the direction of the shift in the EE curve is ambiguous. Consequently $\theta^{*}$ and $K$ may rise or $f a l l$.

Thirdly, if the distribution of $\theta$ changes to dominate the original in the first-order sense, i.e., if larger numbers of domestic managers become more probable, the II curve is unaffected while the EE curve shifts down. Foreign investment falls and the probability of expropriation, $1-\theta^{*}$, rises.

Fourth, an increase in $r$, the world interest rate, shifts the II curve upward while the EE curve is unaffected. The level of investment falls while the probability of expropriation also falls if the EE curve slopes up but rises if it slopes down.

If $s$ rises the EE curve shifts down while the shift in the II curve is ambiguous. The effects on $\theta^{*}$ and $k$ are therefore indeterminate.

Introducing an exogenous penalty in amount $P$ imposed by the investor's country on an expropriating host does not affect the II curve while the EE curve becomes

$\left(7.8^{\prime}\right) \quad E(K, \hat{\mathrm{H}}, \overline{\mathrm{L}})-\mathrm{F}_{\mathrm{K}}(\mathrm{K}-\overline{\mathrm{K}})-\mathrm{s}\left(\hat{\mathrm{H}}-\overline{\mathrm{H}}\left(\theta^{*}\right)\right)=\mathrm{G}\left(\mathrm{K}, \overline{\mathrm{H}}\left(\theta^{*}\right), \overline{\mathrm{L}}\right)-\mathrm{P}$. 
An increase in the penalty shifts the EE curve upward so that the level of investment, $K$, rises while the probability of expropriation, $\theta^{*}$, falls.

As long as capital and managers are complementary factors the penalty raises the income of the host country in any state of nature, even in states where expropriation actually occurs and the penalty is imposed. First, in any state in which expropriation does not occur, host country income rises, as may be shown by differentiating the third part of (7.1) with respect to K. In state $\theta^{*}$ host country income is the same whether or not expropriation occurs. Since $\mathrm{Y}^{\mathrm{N}}\left(\theta^{*}\right)$ rises, so must $\mathrm{Y}^{\mathrm{E}}\left(\theta^{*}\right)$. Thus (7.15) $\frac{\mathrm{dY}^{\mathrm{N}}\left(\theta^{*}\right)}{\mathrm{dP}}=\frac{\mathrm{dY}^{\mathrm{E}}\left(\theta^{*}\right)}{\mathrm{dP}}=\mathrm{G}_{\mathrm{K}}\left(\mathrm{K}, \overline{\mathrm{H}}\left(\theta^{*}\right), \overline{\mathrm{L}}\right) \frac{\mathrm{dK}}{\mathrm{dP}}-1>0$. As long as $G_{K H}>0$, if $G_{K}\left(K, \bar{H}\left(\theta^{*}\right), \bar{L}\right)>1$ then $G_{K} \frac{d K}{d P}>1$ for all $\theta>\theta *$. Thus, even in states where the penalty is imposed, the existence of the penalty raises income: the positive, indirect effect of the penalty in raisIng the level of the capital stock dominates the direct, negative effect of the penalty. 10

In section 2 we discussed the implications of a binding threat of expropriation on income distribution. We now consider the distributional implications of expropriation itself. ${ }^{11}$ of course the effect of expropriation on income distribution depends upon how the income from the expropriated capital is distributed among factors. If expropriation raises national Income as a whole this income can be distributed in a way which harms no domestic factor. For analytic convenience, however, we will assume that Income accrues to a fourth party, perhaps the government.

First, note that if $\overline{\mathrm{H}}(\theta)>\hat{\mathrm{H}}$ when expropriation occurs only $\hat{\mathrm{H}}$ managers will be employed domestically. In this case expropriation does not affect the domestic levels of factor use. Hence, for this case, the act of expropriation has no distributional effects since marginal products are unaffected. 
If, however, $\overline{\mathrm{H}}(\theta)<\hat{\mathrm{H}}$, only $\overline{\mathrm{H}}(\theta)$ managers will be avallable domestically after an expropriation. Managers will gain, since they earn $F_{H}(K, \bar{H}(\theta), \bar{L})>s=$ $F_{H}(K, \hat{H}, \bar{L})$. Labor gains or loses as $F_{L H} \lesseqgtr 0$ while capital gains or loses as $F_{K H} \lesseqgtr 0$; that is, factors complementary with managerial services lose while substitutes gain. Both capital and labor may lose from an expropriation but both cannot gain.

To sumarize, an increase in the probability of expropriation, if expropriation does not occur, tends to benefit national capital, harm labor and leave national managers unaffected relative to a situation of perfect capital mobility. If all factors are complements expropriation itself will either leave all factors unaffected relative to a situation of no expropriation, or harm capital and labor and benefit managers.

Throughout, we have related the expropriation decision to its effect on national income or on the expected utility of national income. Authorities controlling the expropriation decision may be motivated more by the effects of expropriation on various sub-groups rather than on the economy as a whole. An extension of our analysis would be a reformulation of the expropriation criterion to account for these distributional preferences. 


\section{Conclusion}

It is widely recognized that the threat of expropriation can create departures from perfect capital mobility. This threat has usually, however, been treated as an exogenous factor not susceptible of economic analysis. In this paper we have developed a model of expropriation derived explicitly from utility maximizing behavior on the part of host countries and investors. While our basic model is a simple one, in the tradition of neoclassical trade theory, it yields a number of implications about the effects of expropriation on the welfare of the host country, on the distribution of income in the host country, on the appropriate shadow pricing of factors of production, and on the choice of technology in production. While we have explored a number of variants of our model, for instance by introducing uncertainty of two quite different forms, several basic points emerge. The threat of expropriation is detrimental to the welfare of a host country facing competitive foreign investors; domestic capitalists benefit from the threat of expropriation while the effect on labor is detrimental. Domestic managers are unaffected. If the threat of expropriation constrains the level of foreign investment, domestic marginal productivities understate the marginal social product of capital, if capital and managers are complementary, and overstate the marginal social product of managers.

The extent to which a host country is subject to a penalty if it should expropriate actually enhances the welfare of a host country facing competitive potential foreign investors when there is no uncertainty about expropriation. This conclusion is reversed if a foreign investor is in a monopoly position vis-a-vis the host country. If investors are competitive but it is uncertain whether or not expropriation will occur at the time the investment is made, the effect of an expropriation penalty may be ambiguous. As long as 
managers and capital are complements, however, the penalty raises hostcountry income in all states of nature, even those states in which expropriation occurs and the penalty is imposed.

Our theory has a number of implications for empirical research. First, it provides a framework for predicting where deviations from perfect capital mobility are most likely to emerge and suggests a number of testable hypotheses. For example, countries with high endowments of managerial skills relative to physical capital are most likely to remain with a high marginal physical product of capital. Secondly, the stochastic model we develop in Section 7 provides a structure for estimating expropriation probabilities in different countries. Thirdly, our model suggests a number of characteristics of technology and factor employment which might be observed as a consequence of a threat of expropriation. For instance, our model suggests explanations for observed differences in technologies used by foreign and domestic firms in the same country. 
NOTES

1. For instance, Williams (1975) and Jodice (1980) report evidence suggesting that expropriation is particularly frequent in the banking sector and that manufacturing investments are less vulnerable than mining investments.

2. We assume that in the event of expropriation eny asset abroad of the host country will be seized in retaliation. The benefits of expropriation thus depend only upon the net capital position.

3. This assumption is justified if each firm is a minature of the economy (constant returns), if a firm always applies the maximum penalty when any of its capital is seized and if factors are immobile among firms after the decision to invest. In this case the host expropriated all the capital of all foreign firms if it expropiates anything at all. If the second condition is not met consideration should be given to one type of partial expropriation - a takeover of some of each firm's capital. On this point see footnote 7 below. If the third condition is not met, the possibility of a second type of pertial expropriation arises - the complete takeover of some, but not all, firms. In this case, a country might lose access to only the proportion of $\mathrm{H}-\overline{\mathrm{H}}$ corresponding to the proportion of firms expropriated. The host could then re-allocate some of the $\overline{\mathrm{H}}$ to these investments from the investments it did not expropriate. The initial level of foreign investment would have to be such as to prevent this strategy from being optimal for the country since no firm would want to be among the expropriated. A modified version of the EE curve discussed below would be defined by this condition. A model of this second type of partial 
expropriation is similar in conception and results to the model of total expropriation discussed here, but is somewhat more complicated to present.

4. Contrasting the equilibrium where the expropriation threat is binding with the unconstrained equilibrium, note that the capital-1abor ratio is lower in the first situation while the relative magnitude of $H / L$ is higher if capital and management are substitutes but lower if they are complements. Thus, given a production function, the threat of expropriation distorts factor hiring decisions. In Section 5 we discuss how the threat of expropriation may cause firms to modify the production function itself. Forsyth and Solomon (1977) summarize the evidence on differences in factor proportions by nationality of investor. There appears to be no overall tendency for foreign investors to employ different factor proportions than domestic investors. Wide disparities in either direction exist, however, in specific industries. It would be of interest to know if those industries where the risk of expropriation is ceteris paribus greater exhibit relatively labor intensive production by foreign firms.

5. Note that the left-hand side of (2.8a) is the marginal product of capital holding the employment of managers constant at the national endowment level, $\overline{\mathrm{H}}$. The first term on the right-hand side is the marginal product of capital holding the employment of managers at the optimal level when managers are internationally mobile, $\hat{\mathrm{H}}$. Since we assume $\hat{\mathrm{H}}>\overline{\mathrm{H}}$, the first marginal product is greater or less than the second as $\mathrm{F}_{\mathrm{KH}} \lesseqgtr 0$.

6. If we had made the alternative assumption that the wedge $\left(F_{K}-r\right)(K-\bar{K})$ accrued to investors rather than to the host country, our results would be parallel but not identical. The EE curve would remain the same while the relationship 


$$
\mathrm{Y}^{\mathrm{N}}=\mathrm{F}_{\mathrm{K}} \overline{\mathrm{K}}+\mathrm{F}_{\mathrm{L}} \overline{\mathrm{L}}+s \overline{\mathrm{H}}
$$

would define national income and replace the II curve. Denoting this equation the II' curve, note that it lies below the II curve. Thus if foreign investors recelve the rent associated with the threat of expropriation, the equilibrium level of investment and national income will be lower than in the case we consider. If this line of thought is to be pursued, a theory is needed to explain how the right to invest is rationed among competing potential foreign investors. We find it more realistic, however, to assume that host countries are able to exploit their position vis-a-vis competitive investors and capture the rents associated with foreign investment. Note that a tax on foreign investment income at rate $\mathrm{t}_{\mathrm{K}}^{*}$ maximizes not only national income but the level of foreign investment as well. In the range between 0 and $t_{K}^{*}$ an increase in the tax rate on foreign capital income $t_{K}$ actually sumons more foreign capital: as $t_{K}$ rises in this range so do the benefits to the host country of not expropriating. Thus foreign investors can invest more without suffering expropriation.

7. Taxation of foreign capital often takes the form of a requirement that a national of the host country receive a share in the equity of a foreign investment without providing a commensurate share of funds. The host country may not necessarily obtain this transfer via legal means. It may also be effected via bribes, a form of illegal taxation. Foreign investors do, apparently, frequently pay bribes to host country officials for the right to invest. Taxation may even take the form of an anticipated expropriation that 
allows the investor to earn a competitive return on an investment either because the expropriation is partial or because it occurs at a later date (in a multi-period context). Firms invest knowing that time-consistent behavior by the host leads to either of these results. The situation may be explained by the concept of the obsolescing bargain; both parties enter into an agreement anticipating that a shift in their relative strengths will lead to a subsequent renegotiation. Such situations arise and do not imply irrational behavior by investors. Our paper considers an expropriation to render an investment regrettable from the investor's viewpoint (i.e. to lead to a return less than the market return). Our analysis also indicates, however, how the threat of the type of expropriation we do consider makes other forms of (partial) expropriation appropriate as optimal time-consistent taxes.

8. An alternative assumption is that one investor faces one host leading to a Cournot-Nash or similar game theoretic analysis, a topic which we leave to possible future analysis.

9. For instance, $F($ ) might be a three factor production function with ex ante elasticity of substitution $\sigma$ assumed constant and common between all pairs of factors. The parameter $\gamma, 0 \leq \gamma \leq \sigma$ might be the chosen ex post elasticity of substitution. In this case, $\gamma$ would not enter $F()$. If $C(\sigma)=0, \gamma=\sigma$ would be chosen under most circumstances. However, with potential expropriation it may be optimal for the host if firms choose $\gamma<\sigma$ at cost $c(\gamma)>0$. This outcome is preferred because $Y^{N}$ can be raised by the additional deterrent provided by the ex post inflexibility of technology. 
10. When managers and capital are substitutes $\left(F_{\mathrm{KH}}<0\right)$, the possibility arises that in some states in which $\overline{\mathrm{H}}(\theta)>\overline{\mathrm{H}}\left(\theta^{*}\right)$, the increase in $\mathrm{K}$ resulting from the imposition of the penalty does not overcome the negative effect of the penalty itself on income. Because the penalty reduces host-country income in these states of nature, we cannot rule out the possibility that expected host country income falls as a result of a penalty.

11. Tobin (1974) also considers the distributional consequences of an act of expropriation. Since he assumes a linear technology and an arbitrary number of factors, his results differ somewhat. 


\section{REFERENCES}

Eaton, J. and M. Gersovitz, "Debt with Potential Repudiation: Theoretica1 and Emirical Analysis," Review of Economic Studies, vol. 48, no. 152 (1981), pp. 289-309.

Forsyth, D.J.C. and R.E. Solomon, "Choice of Technology and Nationality in Manufacturing in a Develping Country," Oxford Economic Papers, vol. 29, no. 2 (1977), pp. 258-282.

Jodice, D.A., "Sources of Change in Third World Regimes for Foreign Direct Investment 1968-1976," International Organization, vol. 34, no. 2 (1980), pp. $177-206$.

Kydland, R.E. and E.C. Prescott, "Rules Rather Than Discretion: The Inconsistency of Optimal Plans," Journal of Political Economy, 85 (June 1977) pp. $513-548$.

Magee, S.P., "Information and Multinational Corporations: An Appropriability Theory of Direct Foreign Investment," in J.N. Bhagwati (ed.), The New International Economic Order: The North-South Debate (Cambridge: MIT, 1977).

MacDouga11, G.A.D., "The Benefits and Costs of Foreign Investment from Abroad: A Theoretical Approach," Economic Record, vol. 36, no. 1 (1958), pp. 13-35. Tobin, J., "Notes on the Economic Theory of Expulsion and Expropriation," Journal of Development Economics, vo1. 7, no. 1 (1974), pp 7-18.

Williams, M.L., "The Extent and Significance of the Nationalization of Foreign-Owned Assets in Developing Countries 1956-1972, "Oxford Economic Papers, vo1. 27, no. 2 (1975), pp. 260-273. 


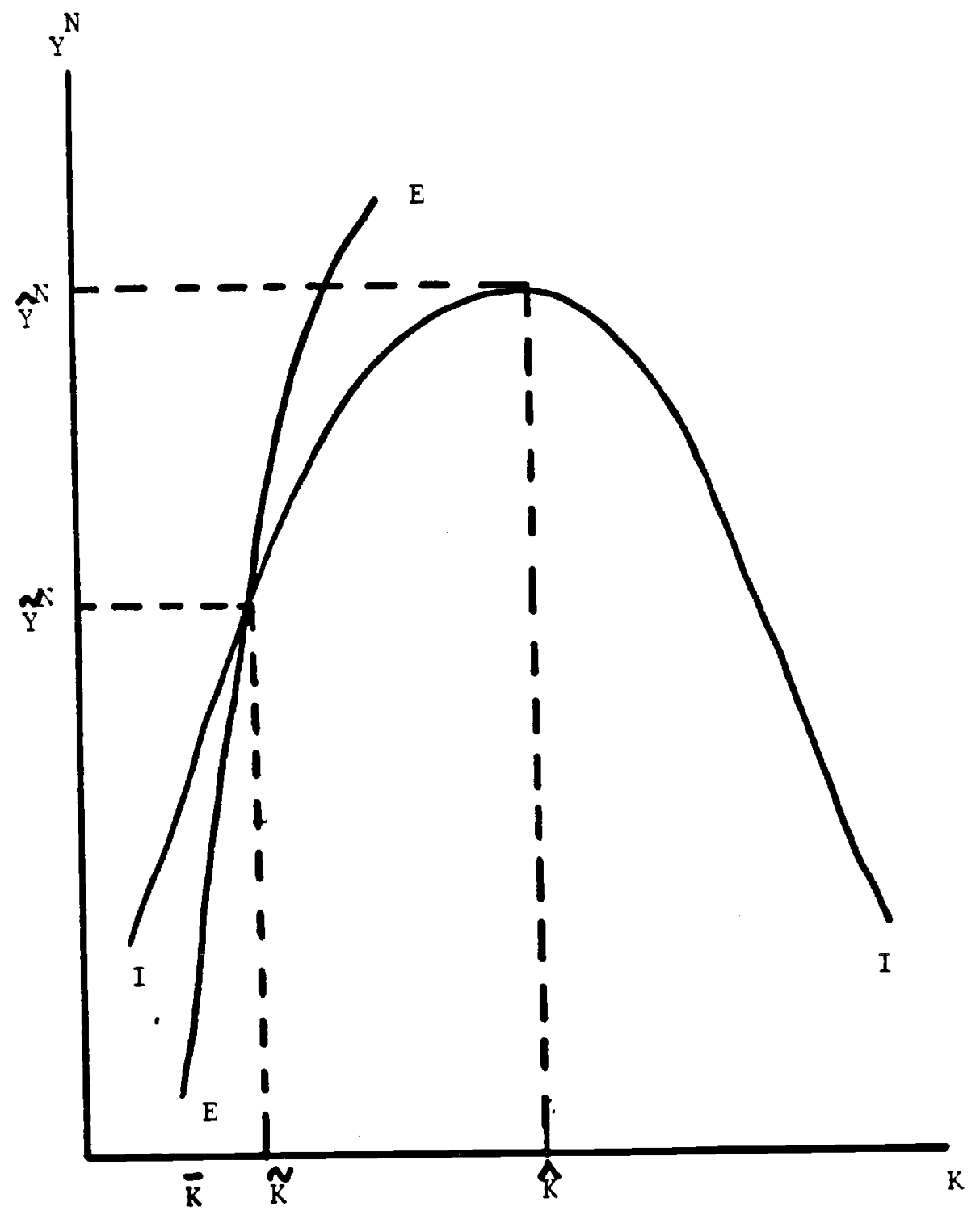

FIGURE 2.1 


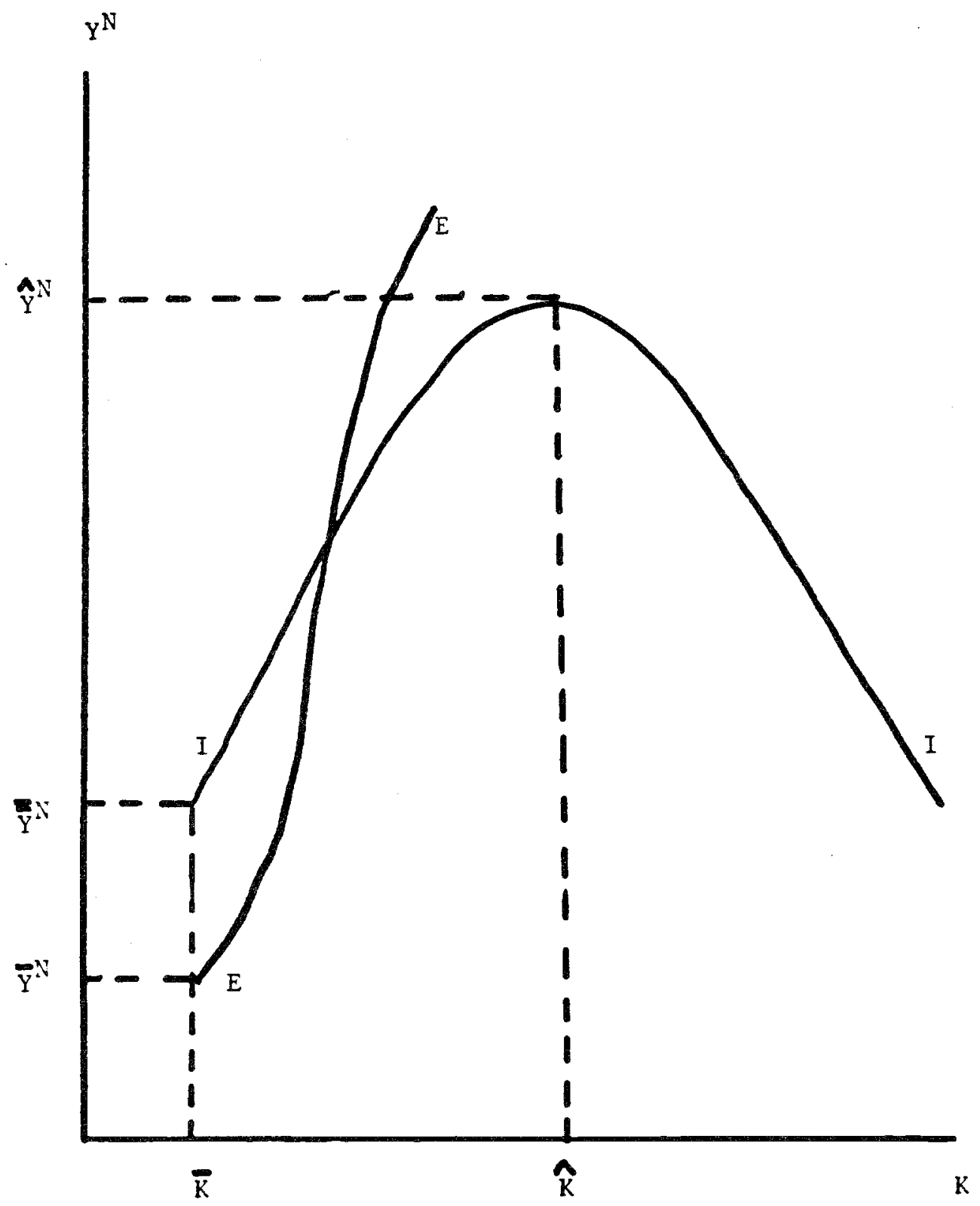

FIGURE 6.1 


$$
b y
$$

